\title{
HER2 status of bone marrow micrometastasis and their corresponding primary tumours in a pilot study of 27 cases: a possible tool for anti-HER2 therapy management?
}

\author{
A Vincent-Salomon ${ }^{*, 1,5}$, J-Y Pierga ${ }^{2,5}$, J Couturier ${ }^{1,5}$, CD d'Enghien', C Nos ${ }^{3}$, B Sigal-Zafrani ', M Lae', \\ P Fréneaux', V Diéras ${ }^{2}, \mathbf{J}-P$ Thiéry ${ }^{4}$ and $X$ Sastre-Garau' \\ 'Department of Tumor Biology, Institut Curie, Paris, France; '²Department of Medical Oncology, Institut Curie, Paris, France; \\ ${ }^{3}$ Department of Surgery, Institut Curie, Paris, France; ${ }^{4}$ Department of Translational Research, Institut Curie, 26 rue d'ulm 75248 Paris, \\ Cedex 05, France
}

Discrepancies have been reported between HER2 status in primary breast cancer and micrometastatic cells in bone marrow. The aim of this study was to assess HER2 gene status in micrometastatic cells in bone marrow and corresponding primary tumour. Micrometastatic cells were detected in bone marrow aspirations in a prospective series of 27 breast cancer patients by immunocytochemistry (pancytokeratin antibody). HER2 status of micrometastatic cells was assessed by fluorescence in situ hybridisation (FISH), respectively in 24 out of 27. Primary tumour HER2 status was assessed by immunohistochemistry (CBII antibody) and by FISH in 20 out of 27 of the cases. HER2 was amplified or overexpressed in five out of 27 (I $8.5 \%$ ) primary tumours and in four out of 27 (15\%) micrometastatic cells. In two cases, HER2 was overexpressed and amplified in primary tumour, but not in micrometastatic cells, whereas, in one case, HER2 presented a low amplification rate (six copies) in micrometastatic cells not found in the primary tumour. We demonstrated that negative and positive HER2 status remained, in the majority of the cases, stable between the bone marrow micrometastasis and the primary tumour. Therefore, the efficiency of anti-HER2 adjuvant therapy could be evaluated, in a clinical trial, by sequential detection of HER2-positive micrometastatic cells within the bone marrow, before and after treatment.

British Journal of Cancer (2007) 96, 654-659. doi: I0.1038/sj.bjc.6603584 www.bjcancer.com

Published online 30 January 2007

(C) 2007 Cancer Research UK

Keywords: breast cancer; HER2; bone marrow; micrometastasis; trastuzumab

HER2 overexpression, observed in $15-30 \%$ of breast cancers, is associated with a poor outcome, especially in node-positive breast carcinoma (Gusterson et al, 1992; Perou et al, 2000). HER2 status remains stable between the primary tumour site and distant metastasis (Niehans et al, 1993; Gancberg et al, 2002; VincentSalomon et al, 2002; Carlsson et al, 2004) or regional lymph node metastasis (Simon et al, 2001). In contrast, HER2 has been found to be overexpressed in $60-100 \%$ in bone marrow micrometastatic cells, independently of the primary tumour status (Braun et al, 2001b). Cytotoxic agents currently used for chemotherapy in highrisk breast cancer patients do not completely eliminate micrometastatic cells in bone marrow (Braun et al, 2000a) and bone marrow micrometastasis in breast cancer patients is associated with a poor outcome (Braun et al, 2000b, 2005; Naume et al, 2004). In this context, a targeted therapy, specific for micrometastatic

*Correspondence: Dr A Vincent-Salomon, Département de Pathologie, Institut Curie, 26 rue d'Ulm, 75248 Paris Cedex 05, France.

E-mail: anne.salomon@curie.net

${ }^{5}$ These authors contributed equally to this work

Received 29 June 2006; revised II December 2006; accepted 12

December 2006; published online 30 January 2007 cells, would be appropriate. However a recent study showed HER2 heterogeneous overexpression in bone marrow micrometastatic cells could be detected in patients with HER2-negative primary tumours. This heterogeneity may reduce the efficacy of an immunotherapy-based strategy in an adjuvant setting (Solomayer et al, 2006). The aim of this pilot study was to assess HER2 gene status by fluorescence in situ hybridisation (FISH) in micrometastatic cells in bone marrow of breast cancer patients and to compare it to HER2 primary tumour status, in order to evaluate if anti-HER2 therapy in adjuvant setting, could be given to patients after an assessment of HER2 status of the primary tumour only. In addition, as the cytokeratin antigens detected in epithelial micrometastatic cells are not specific to cancer cells, morphological analysis of positive detected cells is a major step in the identification of micrometastatic cells. In this perspective, the second aim of our study was to confirm that the isolated cytokeratin-positive $(\mathrm{CK}+)$ cells detected in bone marrow aspirates and interpreted as micrometastasis actually corresponded to tumour cells. We therefore documented the neoplastic nature of the cells by assessing the gene status of other frequently amplified oncogenes in breast carcinomas (Taccagni et al, 1997; Al-Kuraya et al, 2004; Orsetti et al, 2004), especially CCND1 (cyclinD1) and $M Y C$. 


\section{MATERIALS AND METHODS}

\section{Patients}

Cytokeratin positive micrometastatic cells were detected in bone marrow aspirates in a prospective series of breast cancer patients. Bone marrow samples positive for micrometastatic cells and the corresponding primary tumours were obtained from 27 patients (three stage II, one stage III, one local relapse and 22 stage IV). A single bone marrow aspiration was performed under local anaesthesia from the posterior iliac crest before chemotherapy in an adjuvant setting or for metastatic disease. Informed consent was obtained from all patients.

\section{Bone marrow specimens}

Techniques have been described previously (Pierga et al, 2004). Briefly, 3-5 $\mathrm{ml}$ of bone marrow aspirate was collected on EDTA (Vacutainer, Becton Dickinson, Le Pont de Claix, France). Components of the bone marrow aspirate from the two iliac crests were processed under sterile conditions. Each sample was diluted by addition of half the volume of Hanks solution (Gibco BRL, Invitrogen, Cergy, Pontoise, France). Samples were separated by Ficoll/Hypaque density centrifugation (Sigma, St Louis, MO, USA; density, $1.077 \mathrm{~g} \mathrm{ml}^{-1}$ ) in Leucosep tubes (Polylabo, Au Verney, Servion, France) $\left(830 \mathrm{~g}, 15 \mathrm{~min}, 20^{\circ} \mathrm{C}\right)$. The mononuclear cells (MNCs) layer was harvested from each tube, combined, diluted in $50 \mathrm{ml}$ of Hanks and centrifuged at $360 \mathrm{~g}, 5 \mathrm{~min}$ at $20^{\circ} \mathrm{C}$. Cells were resuspended in $\mathrm{PBS} / 0.1 \%$ bovine serum albumin (BSA). After dilution to $3 \%$ in pure acetic acid for red cell lysis, an aliquot of the cell suspension was counted. The MNCs were resuspended in PBS/ BSA at $1.10^{6} \mathrm{ml}^{-1}$. One millilitre of the cell suspension was cytocentrifuged twice onto polylysine-coated slides at $580 \mathrm{~g}$ for 3 min (Hettich Universal 16A cytocentrifuge). The supernatant was carefully removed from each slide after the first cytocentrifugation and the slides were allowed to dry in air overnight. Slides were stored at $-20^{\circ} \mathrm{C}$ and then at $-80^{\circ} \mathrm{C}$ until staining.

\section{Immunocytochemical staining}

The pancytokeratin (CK) monoclonal antibody A45-B/B3 (Micromet, Munich, Germany and Chromavision, San Juan, Capistrano, USA), which recognises several cytokeratin epitopes which characterise CK 8, CK 18 and CK 19, was applied for cell detection (Stigbrand et al, 1998). The immunostaining procedure was standarised by using an automated device (Cadenza, Shandon, France). Before staining, cytospots were fixed with $4 \%$ paraformaldehyde for $5 \mathrm{~min}$, and then dried for $15 \mathrm{~min}$ at room temperature. Endogenous alkaline phosphatase was then blocked with TBS solution (Sigma) with $2 \%$ human AB serum, for $15 \mathrm{~min}$. This solution was used to dilute primary and secondary antibodies. After blocking, the slides were incubated with the primary antibody $\mathrm{A} 45 \mathrm{~B} / \mathrm{B} 3\left(2 \mu \mathrm{g} \mathrm{ml}^{-1}\right.$ for $\left.40 \mathrm{~min}\right)$. Control slides were incubated under the same conditions with a mouse monoclonal anti-FITC IgG1 (1/1250) (Sigma). Slides were incubated for $20 \mathrm{~min}$ with secondary polyclonal rabbit anti-mouse antibody (Dako France, Trappes, France, A/S, Glostrup, Denmark). After each step, the slides were rinsed for $5 \mathrm{~min}$ in TBS $1 \mathrm{X}$ solution. Immune complexes were revealed by the alkaline phosphatase-anti-alkaline phosphatase (APAAP) technique (Dako) (1/50) for $25 \mathrm{~min}$. The chromogen reaction was performed for $20 \mathrm{~min}$ with a colorimetric substrate of fuchsin solution $(2.5 \%$ in $2 \mathrm{~N} \mathrm{HCl})$ (New Fuchsin, Sigma) with $4 \% \quad \mathrm{NaNO}_{2}, 8 \% \quad \beta$-naphthol (Sigma) and $2 \%$ levamisole (Dako). Cells were counterstained with Mayer hematoxylin (1 min) (Sigma) diluted to one out of three in distilled water. The specimen was then rinsed under running water for $5 \mathrm{~min}$ and then in TBS. Slides were coverslipped using Faramount mounting medium (Dako). Mononuclear cells $\left(3 \times 10^{6}\right)$ in three slides were evaluated for each patient. Negative controls, stained with antiFITC monoclonal mouse antibody, were performed on an equivalent number of cells (i.e. three slides, $3 \times 10^{6}$ mononuclear cells) for each patient.

Positive controls were obtained with bone marrow from 'normal' donors undergoing orthopedic surgery, spiked with SKBR3 or MCF7 cell lines, $10-10^{2}$ for $10^{6}$ mononuclear cells per cytospot. One positive control slide and one negative control slide were added to each series of 20 stained slides in the automated device.

\section{$\mathrm{CK}+$ cell detection}

Cell detection was performed by manual screening with an optical microscope. Criteria for evaluation of immunostained cells in bone marrow were adapted from Borgen et al (1999) based on the results of the European ISHAGE Working Group for standarisation of tumour cell detection. The main criteria were a large cell size, a high nuclei/cytoplasm ratio and the absence of obvious haematopoietic cell morphology.

\section{HER2 status}

HER2 status of micrometastatic cells in BM was assessed by FISH on slides on which $\mathrm{CK}+$ cells had been detected. Slides were rinsed in PBS, then treated by pepsin $(0.05 \%$ in $0.01 \mathrm{~N} \mathrm{HCl})$, for $5 \mathrm{~min}$ at $37^{\circ} \mathrm{C}$, then dehydrated in ethanol series. Digoxigeninlabelled HER2 probe solution (Zymed Laboratories Inc., South San Francisco, CA, USA) was laid onto the slides, which were covered by coverslips. In some cases, directly SpectrumOrange-labelled Cyclin D1 or myc probes (Vysis, Downers Grove, IL, USA) were added to the mix in order to increase the probability of detecting abnormal micrometastatic cells. Simultaneous denaturation of the probes and cell DNA was performed at $75^{\circ} \mathrm{C}$ for $2 \mathrm{~min}$. Slides were then incubated overnight at $37^{\circ} \mathrm{C}$ in humid chamber, for hybridisation. Rinsing was performed in $0.4 \times \mathrm{SSC} / 0.3 \%$ Igepal at $75^{\circ} \mathrm{C}$, for $4 \mathrm{~min}$, then in the same solution at $20^{\circ} \mathrm{C}$, for $2 \mathrm{~min}$, followed by $5 \mathrm{~min}$ in PBS. HER2 hybrids were revealed by incubation with a FITC-labeled anti-digoxigenin antibody (Roche Diagnostics, Basel, Switzerland), 1/100 dilution, for $30 \mathrm{~min}$, at $37^{\circ} \mathrm{C}$. Finally, slides were mounted in Vectashield/DAPI (Vector Laboratories, Burlingame, CA, USA). Preparations were analysed by microscope and when technically possible, all $\mathrm{CK}+$ cells detected by their cytoplasmic fluorescence were photographed under FITC, and, in the case of Cyclin D1 or myc hybridisation, under SpectrumOrange excitations.

HER2 status of primary tumour was assessed by immunohistochemistry (CB11 antibody, Novocastra, Newcastle, UK) and by FISH in 20 cases out of the 27 cases, with available and suitable blocks for HER2 FISH analysis.

HER2 immunostainings and FISH were performed on histological tissue sections prepared from a representative sample of the primary tumour. Immunohistochemical procedures for the analysis of HER2 expression were defined to provide a strong correlation between HER2 overexpression and gene amplification status, as determined by FISH (Couturier et al, 2000). After rehydration and antigenic retrieval in citrate buffer (10 mM, pH 6.1), tissue sections were incubated with the CB11 anti-p185 HER/neu monoclonal antibody (Novocastra, Newcastle $\mathrm{UK}$ ), for $1 \mathrm{~h}$, at $1 / 800$ dilution. Staining was revealed with the Vectastain Elite ABC peroxidase mouse IgG kit (Vector Burlingame, CA, USA), using diaminobenzidine (Dako A/S, Glostrup, Denmark) as chromogen. Under these conditions, normal epithelial cells were not immunostained and therefore constituted an internal negative control.

Immunostainings were scored as strong, weak or negative according to the percentage of labelled tumour cells and membrane staining intensity. Cases were considered to be positive 
when at least $60 \%$ of cells were stained (Bilous et al, 2003; VincentSalomon et al, 2003). HER2 status was then classified as overexpressed (strong or moderate staining) or not significantly overexpressed.

Fluorescence in situ hybridisation was performed according to the same protocol as that already described earlier for micrometastasis. In addition, after deparaffinisation, slides were first treated with a protein digesting enzyme, at $37^{\circ} \mathrm{C}$, for $10 \mathrm{~min}$.

Cytokeratins 8/18 expression was also assessed on these 20 out of 27 primary tumours according to a previously published protocol (Azoulay et al, 2005).

\section{RESULTS}

Patient characteristics are summarised in Table 1 . The mean age was 55.6 years (range: $36-75$ years). Tumours were invasive ductal carcinomas in $85 \%$ of cases with a histological grade II or III in $14 / 25$ (56\%).

A visceral metastasis was observed 22 of the cases $(22 / 27$ cases, $81 \%)$. Nineteen cases presented bone metastases $(19 / 27,70 \%$ of cases). Eight of 22 stage IV patients had synchronous metastasis at primary diagnosis. Patients with metastatic disease received chemotherapy as first-line treatment in $65 \%$ of cases (15 patients),

Table I Patients and primary tumour characteristics

\begin{tabular}{|c|c|c|}
\hline Characteristics & $\mathbf{N}=\mathbf{2 7}$ & (\%) \\
\hline \multicolumn{3}{|l|}{ Age(years) } \\
\hline$\leqslant 50$ & 8 & 30 \\
\hline$>50$ & 19 & 70 \\
\hline \multicolumn{3}{|l|}{ Clinical stage } \\
\hline Stage I & 0 & 0 \\
\hline Stage II & 3 & 11 \\
\hline Stage III & I & 4 \\
\hline Stage IV & 22 & 81 \\
\hline Local relapse & 1 & 4 \\
\hline \multicolumn{3}{|l|}{ Tumour size (mm) } \\
\hline$\leqslant 20$ & 5 & 18 \\
\hline ] 20; 40] & 8 & 30 \\
\hline$>40$ & 10 & 37 \\
\hline ND & 4 & 15 \\
\hline \multicolumn{3}{|l|}{ Histological grade } \\
\hline Grade I & 5 & 18 \\
\hline Grade II & 14 & 52 \\
\hline Grade III & 6 & 22 \\
\hline ND & 2 & 7 \\
\hline \multicolumn{3}{|l|}{ Histological type } \\
\hline Ductal invasive & 23 & 85 \\
\hline Lobular invasive & 4 & 15 \\
\hline \multicolumn{3}{|l|}{ Nodal status } \\
\hline 0 & 8 & 30 \\
\hline $1-3$ & 2 & 7 \\
\hline$\geqslant 4$ & 7 & 26 \\
\hline ND & 10 & 37 \\
\hline \multicolumn{3}{|l|}{ Hormonal status } \\
\hline ER+ & 16 & 59 \\
\hline PR+ & 9 & 34 \\
\hline ND & 2 & 7 \\
\hline \multicolumn{3}{|l|}{ Vascular invasion } \\
\hline+ & 13 & 48 \\
\hline- & 6 & 22 \\
\hline ND & 8 & 30 \\
\hline
\end{tabular}

Abbreviation: $\mathrm{ND}=$ not determined. or second-line treatment (four patients)(17.5\%) or third-line treatment (four patients) $(17.5 \%)$.

HER2 status in primary tumours and bone marrow micrometastasis are summarised in Table 2. 6/27 (22.2\%) primary tumours had HER2 overexpression $(2+$ and $3+)$. In five cases, the intensity of staining was strong $(3+)$ and observed in $100 \%$ of tumour cells of the invasive component. In 4/4 (100\%) cases assessable for FISH analysis, this overexpression was associated to HER2 amplification. The remaining case with moderate $(++)$ staining did not show any amplification by FISH. Therefore, $5 / 27(18.5 \%)$ tumours presented HER2 amplification and overexpression.

Micrometastatic cells in bone marrow were observed in all selected cases. The cell morphology on cytospots was interpreted according to the ISHAGE criteria for tumour cells. The cells were large, with a high nucleus/cytoplasm ratio. In 19 out of 27 cases, the micrometastatic cells formed clusters. The number of micrometastatic cells ranged from 1 to 1500 per slide examined.

In four out of 27 (15\%) (95\%CI: 2-28\%) cases HER2 amplification was observed in bone marrow micrometastatic cells. When more than 20 cells were observed and interpretable the amplification was homogeneous. In two cases, HER2 was amplified and overexpressed in the primary tumour, but not in distant BM micrometastatic cells and in one case, HER2 presented a very low level of amplification in BM micrometastatic cells (six copies) and not in the primary tumour (two copies). At least, only two (50\%) of four cases with HER-2 amplification in primary tumours showed HER-2 amplification in micrometastatic cells, and three (75\%) of

Table 2 Descriptive results of HER2 status in primary tumours and in bone marrow by FISH and by immunohistochemistry

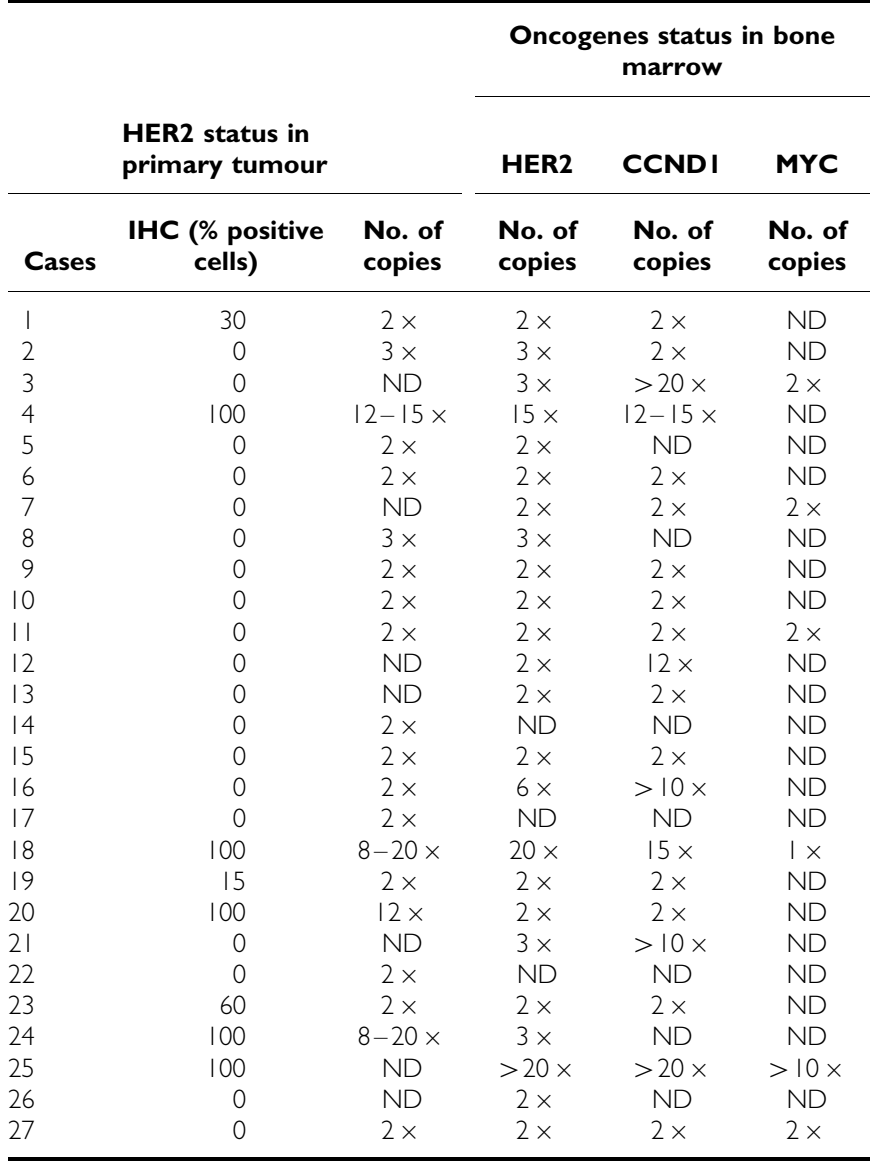

Abbreviations: $\mathrm{ND}=$ not determined; FISH: fluorescence in situ hybridization; $\mathrm{IHC}$ Immunohistochemistry. 


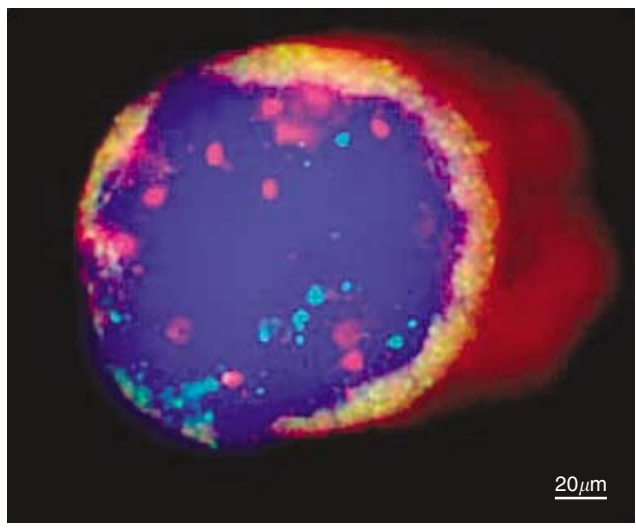

Figure I One micrometastatic cell CK+ (intracytoplasmic red labelling) with HER 2 amplification (red spots) and CCNDI amplification (green spots).

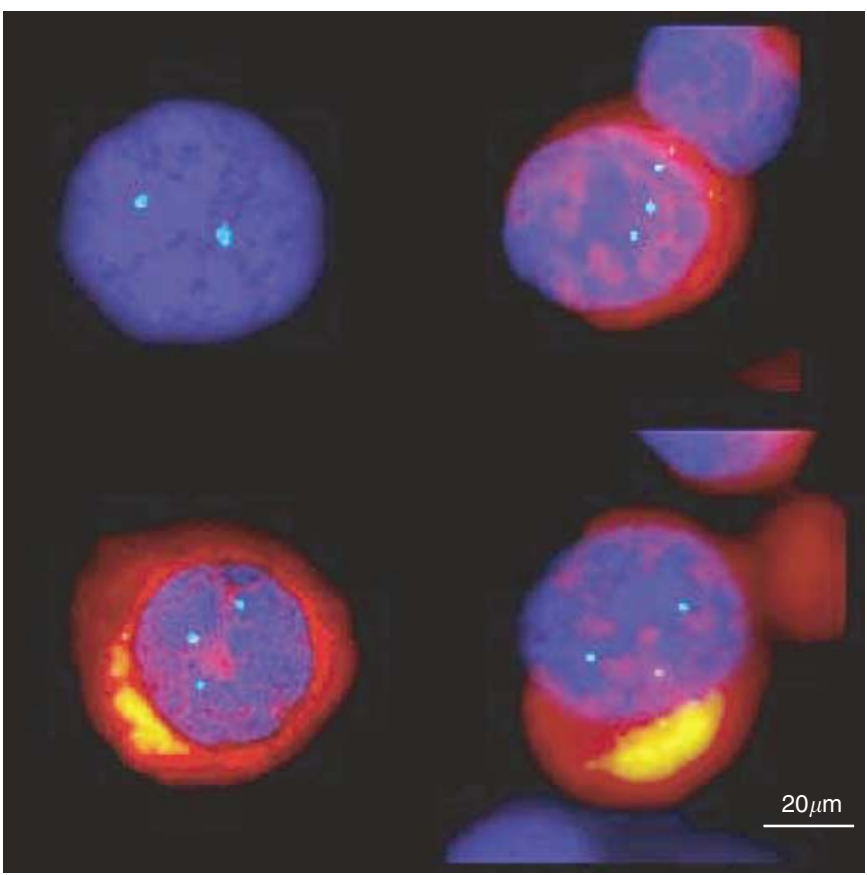

Figure 2 Chromosome 17 trisomy (blue spots) in $\mathrm{CK}+$ cells (cytoplasmic red labelling) and disomy (blue spots) in cytokeratine-negative cell.

four cases with HER-2 amplification in micrometastatic cells showed HER-2 amplification in the primary tumours.

CCND1 gene status was assessed in 20/27 of the cases. CCND1 was amplified in seven of these 20 cases (35\%). Notably, four of these seven CCND1 amplified cases showed also an amplification of HER2 (Figure 1). In the remaining three cases, this amplification confirmed that the detected HER2-negative $\mathrm{CK}+$ cells actually corresponded to tumour cells.

MYC gene status was assessed in six cases and was amplified in one case, in which HER2 and CCND1 were also amplified (Table 2).

Four cases, without HER2 amplification, presented three HER2 gene copies per nucleus and thus demonstrated a HER2 overrepresentation in relation with a chromosome 17 trisomy. The presence of chromosome 17 trisomy was another proof of malignancy of these micrometastatic cells (Figure 2) (Table 2).
All analysed cases showed cytokeratin $8 / 18$ expression in their primary breast tumour, ranging from 10 to $100 \%$ of positive cells per case.

\section{DISCUSSION}

In this pilot study, we wanted to document the stability of the HER2 status between primary tumours and their bone marrow micrometastasis. We observed that the majority of the HER2negative tumours were associated with HER2-negative micrometastasis except in one case in which micrometastatic cells demonstrated a lower level of HER2 amplification. In addition, in our series of breast carcinomas, $15 \%$ of bone marrow micrometastatic cells presented HER2 amplification. This rate is very close to that observed in primary breast tumours. HER2 gene amplification appears thus to occur before bone marrow micrometastatic process in breast cancer and to remain stable during bone marrow micrometastatic spread.

This result is in accordance with those concerning visceral metastases and local and regional metastases (Barnes et al, 1988; Niehans et al, 1993; Masood and Bui, 2000; Simon et al, 2001; Gancberg et al, 2002; Vincent-Salomon et al, 2002; Carlsson et al, 2004). Recently, in a meta-analysis of the published data concerning HER2 status stability among primaries and metastases, Carlsson et al (2004) confirmed that there was no drastic modification in HER2 status between primary tumours and their locoregional lymph node metastases and their distant visceral metastases.

Our results and these published data on the stability of HER2 status between primary and metastatic tumours are in contrast with the recently published studies by Schmidt-Kittler et al (2003) and by Klein et al (Mercapide et al 2002) showing that micrometastatic cells demonstrated fewer chromosomal alterations, such as losses and gains detected by single-cell CHG analysis, than primary tumour cells (Mercapide et al 2002; Schmidt-Kittler et al, 2003). Another recently published study also showed that HER2 amplification was more frequently observed in circulating cells than in primary tumours and therefore concluded that HER2 amplification could be acquired during the metastatic process (Meng et al, 2004). The HER2 amplicon corresponds to a $280-\mathrm{kb}$ minimal region of amplification at the HER2 locus of chromosome $17 \mathrm{q}$ arm, in breast cancer. The amplification is significantly associated with increased expression of six of the 10 genes located within this region (HER2, GRB7, PNMT, MLN64, MGC9753 and MGC 1483) as described by Kauraniemi et al (2003). This amplicon has been observed since the early stage of in situ carcinoma (Van de Vijver et al, 1988). The observation of HER2 amplification exclusively in disseminated cells, suggests a selection of clones within the primary tumour that harboured initial HER2 amplification and that were underrepresented in the primary tumour, for example, by cytotoxic agents, rather than an acquisition of this amplification de novo within the metastatic cells.

Previous studies by Pantel et al (1993), Braun et al (2001a) and Solomayer et al (2006), reported high rates of HER2 overexpression ranging from 60 to $100 \%$ of cases, analysed by immunocytochemistry only. These rates could therefore be explained by technical aspects, that is, excessively sensitive immunohistochemistry technique. Using the FISH approach, we demonstrated that primary breast tumours and bone marrow micrometastasis demonstrate the same range of HER2 activation, ranging around $15 \%$ of the cases (Table 3 ).

The gene expression profile of metastasis and their primaries has also been compared and has been shown to cluster together (Ramaswamy et al, 2003; Weigelt et al, 2003). In the literature, Cyclin D1 amplification in primary breast tumours ranged between 10 and $23 \%$. In our series, the CyclinD1 (CCND1) amplification 
Table 3 Correlation between HER2 status assessed by $\mathrm{FISH}$ in micrometastatic cells and by FISH and or immunohistochemistry in primary tumors

HER2 status in primary tumors $(n=27)$

\begin{tabular}{lcc}
$\begin{array}{l}\text { HER2 status in } \\
\text { micrometastatic cells }\end{array}$ & $\begin{array}{c}\text { Amplified/ } \\
\text { overexpressed }\end{array}$ & Not amplified \\
\hline Amplified & 3 & 1 \\
Not amplicited & 2 & 21 \\
Total & 5 & 22
\end{tabular}

Abbreviation: FISH: fluorescence in situ hybridization; IHC: Immunohistochemistry

rate was 35\% (Al-Kuraya et al, 2004). This rate is therefore higher than previously reported for ductal carcinomas, although our series is very small to derive any conclusions about this issue. However, we can speculate that the amplification rate might be higher in this group of metastatic and advanced breast carcinomas. Amplification of HER2 with other oncogenes has been reported

\section{REFERENCES}

Al-Kuraya K, Schraml P, Torhorst J, Tapia C, Zaharieva B, Novotny H, Spichtin H, Maurer R, Mirlacher M, Kochli O, Zuber M, Dieterich H, Mross F, Wilber K, Simon R, Sauter G (2004) Prognostic relevance of gene amplifications and coamplifications in breast cancer. Cancer Res 64: $8534-8540$

Azoulay S, Lae M, Freneaux P, Merle S, Al Ghuzlan A, Chnecker C, Rosty C, Klijanienko J, Sigal-Zafrani B, Salmon R, Fourquet A, Sastre-Garau X, Vincent-Salomon A (2005) KIT is highly expressed in adenoid cystic carcinoma of the breast, a basal-like carcinoma associated with a favorable outcome. Mod Pathol 18: 1623-1631

Barnes DM, Lammie GA, Millis RR, Gullick WL, Allen DS, Atman DG (1988) An immunohistochemical evaluation of c-erbB-2 expression in human breast carcinoma. Br J Cancer 58: $448-452$

Bilous M, Dowsett M, Hanna W, Isola J, Lebeau A, Moreno A, PenaultLlorca F, Ruschoff J, Tomasic G, van de Vijver M (2003) Current perspectives on HER2 testing: a review of national testing guidelines. Modern Pathol 16: $173-182$

Borgen E, Naume B, Nesland JM, Kvalheim G, Beiske K, Fodstad O, Diel I, Solomayer EF, Theocharous P, Coombes RCS, BM, Wunder E, Marolleau J-P, Garcia J, Pantel K (1999) Standardization of the immunocytochemical detection of cancer cells in BM and blood: I. establishment of objective criteria for the evaluation of immunostained cells. Cytotherapy 1: $377-388$

Braun S, Cevatli BS, Assemi C, Janni W, Kentenich CRM, Schindlbeck C, Rjosk D, Hepp F (2001a) Comparative analysis of micrometastasis to the bone marrow and lymph nodes of node-negative breast cancer patients receiving no adjuvant therapy. J Clin Oncol 19: 1468-1475

Braun S, Kentenich C, Janni W, Hepp F, de Waal J, Willgeroth F, Sommer H, Pantel K (2000a) Lack of effect of adjuvant chemotherapy on the elimination of single dormant tumor cells in bone marrow of high-risk breast cancer patients. J Clin Oncol 18: 80-86

Braun S, Pantel K, Muller P, Janni W, Hepp F, Kentenich CRM, Gastroph S, Wischnik A, Dimpfl T, Kindermann G, Riethmuller G, Schlimok G (2000b) Cytokeratin-positive cells in the bone marrow and survival of patients with stage I, II, or III breast cancer. N Engl J Med 342: 525-533

Braun S, Schlimok G, Heumos I, Schaller G, Riethdorf L, Riethmuller G, Pantel K (2001b) ErbB2 overexpression on occult metastatic cells in bone marrow predicts poor clinical outcome of stage I-III breast cancer patients. Cancer Res 61: $1890-1895$

Braun S, Vogl FD, Naume B, Janni W, Osborne MP, Coombes RC, Schlimok G, Diel IJ, Gerber B, Gebauer G, Pierga JY, Marth C, Oruzio D, Wiedswang G, Solomayer EF, Kundt G, Strobl B, Fehm T, Wong GY, Bliss J, Vincent-Salomon A, Pantel K (2005) A pooled analysis of bone marrow micrometastasis in breast cancer. $N$ Engl J Med 353: 793-802

Carlsson J, Nordgren H, Sjostrom J, Wester K, Villman K, Bengtsson NO, Ostenstad B, Lundqvist H, Blomqvist C (2004) HER2 expression in breast previously, particularly in a recently published FISH study (AlKuraya et al, 2004). In this work, HER2 was associated with CCND1 amplification in $18 \%$ of cases. CCND1 was amplified in $20 \%$ of cases. Determination of coamplification rates of major oncogenes such as $M Y C$ and CCND1 in breast carcinomas should provide important information regarding prognosis. It has also been recently reported, during the 2005 San Antonio meeting, that MYC status could be a predictive parameter of tumour response to antiHER2 therapy (Gianni et al, 2005).

In conclusion, the HER2 status assessed by FISH in isolated micrometastatic cancer cells in bone marrow was well correlated with that of primary tumour. Our pilot study showed that in the majority of the cases, the stable, positive or negative, status of HER2 during the bone marrow micrometastatic process. This observation on a small series of cases should be confirmed on a larger scale and identification of HER2-positive micrometastatic cells in breast carcinomas could constitute part of patient management in a future clinical trial, in order to select patients for anti-HER2 adjuvant therapy. Repeated assessment of the presence of micrometastases could also be part of the follow-up and evaluation of the efficacy of anti-HER2 therapy. cancer primary tumours and corresponding metastases. Original data and literature review. Br J Cancer 90: 2344-2348

Couturier J, Vincent-Salomon A, Nicolas A, Zafrani B, Sastre-Garau X (2000) Strong correlation between results of fluorescent in situ hybridization and immunohistochemistry for the assessment of ERBB2 (HER-2/neu) gene status in breast carcinoma. Modern Pathol 13: $1238-1243$

Gancberg D, Di Leo A, Cardoso F, Rouas G, Pedrocchi M, Paesmans M, Verhest A, Bernard-Marty C, Piccart MJ, Larsimont D (2002) Comparison of HER-2 status between primary breast cancer and corresponding distant metastatic sites 10.1093/annonc/mdf252. Ann Oncol 13: $1036-1043$

Gianni L, Zambetti M, Clark K, Baker J, Cronin M, Wu J, Mariani G, Rodriguez J, Carcangiu M, Watson D, Valagussa P, Rouzier R, Symmans W, Fraser R, Jeffrey S, Hortobagyi GN, Pusztai L, Shak S (2005) Gene expression profiles in paraffin-embedded core biopsy tissue predict response to chemotherapy in women with locally advanced breast cancer. J Clin Oncol 23: 7265-7277

Gusterson BA, Gelber RD, Goldhirsch A, Price KN, Save-Soderborgh J, Anbazhagan R, Styles J, Rudenstam CM, Golouh R, Reed R, Martinez-Tello F, Tiltman A, Grigolato P, Bettelehim R, Neville AM, Bürki K, Castiglione M, Collins J, Lindtner J, Stenn H-J (1992) Prognostic importance of c-erbB-2 expression in breast cancer. International (Ludwig) Breast Cancer Study Group.. J Clin Oncol 10: $1049-1056$

Kauraniemi P, Kuukasjarvi T, Sauter G, Kallioniemi A (2003) Amplification of a 280-kilobase core region at the ERBB2 locus leads to activation of two hypothetical proteins in breast cancer. Am J Pathol 163: 1979-1984 Masood S, Bui MM (2000) Assessment of Her2/neu overexpression in primary breast cancers and their metastatic lesions: an immunohistochemical study. Annals Clin Laboratory Sci 30: 259-265

Meng S, Tripathy D, Shete S, Ashfaq R, Haley B, Perkins S, Beitsch P, Khan A, Euhus D, Osborne C, Frenkel E, Hoover S, Leitch M, Clifford E, Vitetta E, Morrison L, Herlyn D, Terstappen LW, Fleming T, Fehm T, Tucker T, Lane N, Wang J, Uhr J (2004) HER-2 gene amplification can be acquired as breast cancer progresses. Proc Natl Acad Sci USA 101: 9393-9398

Mercapide J, Zhang S, Fan X, Furio-Bacete V, Schneider J, Lopez de la Osa I, Patchefsky A, Klein-Szanto A, Castresana J (2002) CCND1- and ERBB2gene deregulation and PTEN mutation analyses in invasive lobular carcinoma of the breast. Mol Carcinogen 35: 6-12

Naume B, Wiedswang G, Borgen E, Kvalheim G, Karesen R, Qvist H, Janbu J, Harbitz T, Nesland JM (2004) The prognostic value of isolated tumor cells in bone marrow in breast cancer patients: evaluation of morphological categories and the number of clinically significant cells. Clin Cancer Res 10: 3091-3097 
Niehans GA, Singleton TP, Dykoski D, Kiang DT (1993) Stability of HER-2/ neu expression over time and at multiple metastatic sites. J Natl Cancer Inst 85: $1230-1235$

Orsetti B, Nugoli M, Cervera N, Lasorsa L, Chuchana P, Ursule L, Nguyen C, Redon R, du Manoir S, Rodriguez C, Theillet C (2004) Genomic and expression profiling of chromosome 17 in breast cancer reveals complex patterns of alterations and novel candidate genes. Cancer Res 64: $6453-6460$

Pantel K, Schlimok G, Braun S, Kutter D, Lindemann F, Schaller G, Funke I, Izbicki JR, Riethmuller G (1993) Differential expression of proliferationassociated molecules in individual micrometastatic carcinoma cells. I Natl Cancer Inst 85: 1419-1424

Perou CM, Sorlie T, Eisen MB, van de Rijn M, Jeffrey SS, Rees CA, Pollack JR, Ross DT, Johnsen H, Akslen LA, Fluge O, Pergamenschikov A, Williams C, Zhu SX, Lonning PE, Borresen-Dale AL, Brown PO, Botstein D (2000) Molecular portraits of human breast tumours. Nature 406: $747-752$

Pierga JY, Bonneton C, Vincent-Salomon A, de Cremoux P, Nos C, Blin N, Pouillart P, Thiery JP, Magdelenat H (2004) Clinical significance of immunocytochemical detection of tumor cells using digital microscopy in peripheral blood and bone marrow of breast cancer patients. Clin Cancer Res 10: $1392-1400$

Ramaswamy S, Ross KN, Lander ES, Golub TR (2003) A molecular signature of metastasis in primary solid tumors. Nat Genet 33: 49-54

Schmidt-Kittler O, Ragg T, Daskalakis A, Granzow M, Ahr A, Blankenstein TJF, Kaufmann M, Diebold J, Arnholdt H, Muller P, Bischoff J, Harich D, Schlimok G, Riethmuller G, Eils R, Klein CA (2003) From latent disseminated cells to overt metastasis: genetic analysis of systemic breast cancer progression. Proc Natl Acad Sci USA 100: 7737-7742

Simon R, Nocito A, Hübscher T, Bucher C, Torhorst J, Schraml P, Bubendorf L, Mihatsch M, Moch H, Wilber K, Schötzau A, Kononen J, Sauter G (2001) Patterns of HER-2/neu amplification and overexpression in primary and metastatic breast cancer. I Natl Cancer Inst 93: $1141-1146$

Solomayer EF, Becker S, Pergola-Becker G, Bachmann R, Kramer B, Vogel U, Neubauer H, Wallwiener D, Huober J, Fehm TN (2006) Comparison of HER2 status between primary tumor and disseminated tumor cells in primary breast cancer patients. Breast Cancer Res Treat 98: $179-184$

Stigbrand T, Andres C, Bellanger L, Bishr Omary M, Bodenmuller H, Bonfrer H, Brundell J, Einarsson R, Erlandsson A, Johansson A, Leca JF, Levi M, Meier T, Nap M, Nustad K, Seguin P, Sjodin A, Sundstrom B, van Dalen A, Wiebelhaus E, Wiklund B, Arlestig L, Hilgers J (1998) Epitope specificity of 30 monoclonal antibodies against cytokeratin antigens: the ISOBM TD5-1 workshop. Tumour Biol 19: 132-152

Taccagni G, Rovere E, Masullo M, Christensen L, Eyden B (1997) Myofibrosarcoma of the breast. Review of the literature on myofibroblastic tumors and criteria for defining myofibroblastic differentiation. Am J Surg Pathology 21: 489-496

Van de Vijver MJ, Peterse JL, Mooi WJ, Wisman P, Lomans J, Dalesio O, Nusse R (1988) Neu-protein overexpression in breast cancer. Association with comedo-type ductal carcinoma in situ and limited prognostic value in stage II breast cancer. $N$ Engl J Med 319: $1239-1245$

Vincent-Salomon A, Jouve M, Genin P, Fréneaux P, Sigal-Zafrani B, Caly M, Beuzeboc P, Pouillart P, Sastre-Garau X (2002) HER2 status in patients with breast carcinomas is not modified selectively by preoperative chemotherapy and is stable during the metastatic process. Cancer 94: $2169-2173$

Vincent-Salomon A, Mac Grogan G, Couturier J, Arnould L, MathoulinPélissier S (2003) Re: HER2 testing in the real world. J Natl Cancer Inst 95: $628-629$

Weigelt B, Glas AM, Wessels LF, Witteveen AT, Peterse JL, van't Veer LJ (2003) Gene expression profiles of primary breast tumors maintained in distant metastases. Proc Natl Acad Sci USA 100: 15901 - 15905 